\title{
Preparation of trans-1,2-Diaminocyclohexanetetrachloroplatinum(IV)
}

\author{
A. K. Starkov*, R. F. Mulagaleev, and S. D. Kirik \\ Institute of Chemistry and Chemical Technology, Siberian Branch, Russian Academy of Sciences, Krasnoyarsk, Russia \\ *E-mail: kaz@ioot.ru \\ Received March 17, 2011
}

DOI: $10.1134 / \mathrm{S} 1070328411090090$

The complex trans-1,2-diaminocyclohexanetetrachloroplatinum(IV) (ormaplatin, tetraplatin) is a second generation antitumor drug, which is similar in efficiency with respect to various tumors but less nephrotoxic than cis-dichlorodiaminoplatinum(II) (cisplatin). It is also efficient against the human and murine tumor cells having the acquired resistance to cisplatin [1]. The preparation of this compound is based on the reactions(1) [2, 3] and (2) [1,4] where 1,2-Dach is trans-1,2-d,l-diaminocyclohexane):

$$
\begin{gathered}
\mathrm{K}_{2}\left[\mathrm{PtCl}_{4}\right]+1,2-\mathrm{Dach} \\
\frac{\mathrm{H}_{2} \mathrm{O}}{\mathrm{N}_{2}}\left[\mathrm{Pt}(1,2-\mathrm{Dach}) \mathrm{Cl}_{2}\right] \\
\frac{\mathrm{DMF}, \mathrm{HC} / \mathrm{Cl}_{2}}{100^{\circ} \mathrm{C}}\left[\mathrm{Pt}(1,2-\mathrm{Dach}) \mathrm{Cl}_{4}\right], \\
\mathrm{K}_{2}\left[\mathrm{PtCl}_{6}\right]+1,2-\mathrm{Dach} \rightarrow\left[\mathrm{Pt}(1,2-\mathrm{Dach}) \mathrm{Cl}_{4}\right] .
\end{gathered}
$$

This communication presents a new procedure for the preparation of $\left[\mathrm{Pt}(1,2-\mathrm{Dach}) \mathrm{Cl}_{4}\right]$.

1,2 -Dach $\cdot 2 \mathrm{HCl}\left(0.74 \mathrm{~g},\left(3.96 \times 10^{-3} \mathrm{~mol}\right)\right.$ in $3 \mathrm{M}$ $\mathrm{HCl}(5 \mathrm{~mL})$ was added at room temperature to $\mathrm{H}_{2}\left[\mathrm{PtCl}_{6}\right] \cdot 6 \mathrm{H}_{2} \mathrm{O}\left(2 \mathrm{~g}, 3.85 \times 10^{-3} \mathrm{~mol}\right)$. After $30 \mathrm{~min}$, the precipitate was filtered off and dried in vacuum. Water $(15 \mathrm{~mL})$ was added to the resulting intermediate product $\left(1,2-\mathrm{DachH}_{2}\right)\left[\mathrm{PtCl}_{6}\right]\left(1.81 \mathrm{~g}, 3.46 \times 10^{-3} \mathrm{~mol}\right)$, and the mixture was kept for $2 \mathrm{~h}$ at room temperature. After the supernatant solution became pale yellow, the process was terminated, and the resulting precipitate of the target product was filtered off, washed with ethanol, and dried. The yield of $\left[\mathrm{Pt}(1,2-\mathrm{Dach}) \mathrm{Cl}_{4}\right]$ was $1.24 \mathrm{~g}(80 \%)$.
The composition of the compound was confirmed by elemental analysis (platinum was quantified by the gravimetric method, and carbon, hydrogen, and nitrogen were quantified on a EA 1108 CHNS analyzer). The individual character of $\left[\mathrm{Pt}(1,2-\mathrm{Dach}) \mathrm{Cl}_{4}\right]$ was proved by powder X-ray diffraction [5] and IR and UV spectroscopy.

The preparation of the complex $\left[\mathrm{Pt}(1,2-\mathrm{Dach}) \mathrm{Cl}_{4}\right]$ by reactions (1) and (2) is rather complicated and requires the use of additional reagents, in particular, DMF and gaseous chlorine for reaction (1) and acetone and ether for reaction (2). To perform reaction (2), repeated evaporation with successive carrying out of chemical operations was used [1, 4], which markedly decreased the yield of the target product (54\%) and increases the duration of synthesis.

Using the proposed procedure, $\left[\mathrm{Pt}(1,2-\mathrm{Dach}) \mathrm{Cl}_{4}\right]$ can be obtained markedly more easily and in a higher yield.

\section{REFERENCES}

1. Wyrig, S.D. and Chaney, S.G., J. Labelled Compd. Radiopharm., 1990, vol. 28, no. 7, p. 753.

2. Eastland, G.J., Drugs Fut., 1987, vol. 12, no. 2, p. 139.

3. Anderson, W.K., Quagliato, D.A., Haugwitz, R.D., et al., Cancer Treat. Rep., 1986, vol. 70, p. 997.

4. Upjohn, Natl Cancer Inst., Drugs Fut., 1991, vol. 16, no. 2, p. 187.

5. Khokhar, A.R., Xu, Q., and Al-Baker, S., J. Inorg. Biochem., 1993, vol. 52, no. 1, p. 51. 